\title{
A DIRECT METHOD FOR THE DETERMINATION OF VENOUS PRESSURE; RELATIONSHIP OF TISSUE PRESSURE TO VENOUS PRESSURE
}

\author{
By GEORGE E. BURCH AND WILLIAM A. SODEMAN \\ (From the Department of Medicine, Tulane University of Louisiana, School of Medicine, and \\ the Charity Hospital of Louisiana, New Orleans)
}

(Received for publication August 22, 1938)

Previous observations (2) indicate that there is a positive pressure in the tissue spaces. It is obvious that any pressure manipulations of the tissues must take into consideration this extravascular, or tissue, pressure. Tissue pressure is exerted upon all the contained structures, including the blood vessels and opposes the intravascular pressure. In the arterial tree, where the intravascular pressures are high, this is relatively insignificant. However, in the venous vessels, where the intravascular pressure approaches the tissue pressure, particularly above heart level, this effect becomes increasingly important. The present study is concerned with an evaluation of the interplay of these pressures and their influence upon the determination of venous pressure by indirect methods.

\section{METHODS AND MATERIALS}

The indirect measurements of venous pressure were made according to the method of Hooker (1). Definite collapse of the vessel was used as the end point. Collapse was never carried beyond the level of the adjacent skin. Tissue pressure determinations were made by the technic previously described (2). The direct determinations of venous pressure were made with the apparatus employed in the tissue pressure measurements. However, the technic was modified as follows. A 2 per cent sodium citrate solution was used instead of normal sodium chloride. The solution was drawn about half way up the adapter, to compensate for capillarity, as in tissue pressure determinations, and the pressure within the system brought to atmospheric. Upon insertion of the needle into the vein the meniscus in the adapter slowly began to rise. The pressure in the system was gradually increased until the movement of the meniscus ceased and there was no movement into or out of the vein. This was taken as the venous pressure.

Studies were made on ten normal subjects. Only subjects with prominent veins in the dorsum of the hand were chosen so as to facilitate the reading of the end point in the indirect venous pressure method. Subjects rested in the sitting position with the hand at heart level, fourth intercostal space. Indirect and direct venous pres- sures were determined for the same portion of the same vein on the dorsum of the hand. The subcutaneous tissue pressure was then measured in the tissues immediately surrounding the same portion of the vein.

Determinations were made in the order given. The observer who read the end points was ignorant of the water manometer readings, which were recorded by another individual. In this way subjective influences were eliminated. Three readings were made in each instance.

\section{RESULTS}

The results are given in Table I. Invariably, the indirect determinations were lower than the

TABLE I

Venous pressure and tissue pressure values in cm. of water at heart level in ten normal subjects

\begin{tabular}{c|c|c|c|c|c}
\hline \hline $\begin{array}{c}\text { Subject } \\
\text { number }\end{array}$ & $\begin{array}{c}\text { Venous } \\
\text { pressure } \\
\text { direct }\end{array}$ & $\begin{array}{c}\text { Venous } \\
\text { pressure } \\
\text { indirect }\end{array}$ & $\begin{array}{c}\text { Tissue } \\
\text { pressure }\end{array}$ & $\begin{array}{c}\text { Indirect } \\
\text { venous } \\
\text { pressure } \\
+ \text { tissue } \\
\text { pressure }\end{array}$ & $\begin{array}{c}\text { Difference between } \\
\text { direct venous } \\
\text { pressure and } \\
\text { indirect venous } \\
\text { pressure +t tissue } \\
\text { pressure }\end{array}$ \\
\hline & $c m . H_{2} O$ & $c m . H_{2} O$ & $c m . H_{2} O$ & $c m . H_{2} O$ & $c m . H_{2} O$ \\
1 & 14.2 & 11.0 & 1.8 & 12.8 & -1.4 \\
2 & 14.6 & 9.4 & 5.4 & 14.8 & +0.8 \\
3 & 13.0 & 9.2 & 2.6 & 11.8 & +1.2 \\
4 & 7.8 & 6.0 & 3.2 & 9.2 & +1.4 \\
5 & 13.2 & 7.4 & 2.9 & 10.3 & -2.9 \\
6 & 12.4 & 11.8 & 2.2 & 14.0 & +1.6 \\
7 & 7.8 & 5.2 & 3.2 & 8.4 & +0.6 \\
8 & 9.6 & 8.4 & 2.6 & 11.0 & +1.4 \\
9 & 9.4 & 7.6 & 1.8 & 9.4 & 0.0 \\
10 & 10.4 & 8.4 & 3.0 & 11.4 & -1.0 \\
Mean & 11.2 & 8.4 & 2.9 & 11.3 & +0.1 \\
\hline
\end{tabular}

corresponding direct determinations. The average indirect value was $8.4 \mathrm{~cm}$. of water and the average direct value was $11.2 \mathrm{~cm}$. of water. The average determination of tissue pressure was 2.9 $\mathrm{cm}$. of water. Individual determinations may be seen in Table I. It is also evident in Table I that the addition of the indirect venous pressure and tissue pressure closely approximates the direct venous pressure, the mean difference being only $0.1 \mathrm{~cm}$. of water. 
Following the determination of direct venous pressure in $\mathbf{5}$ subjects prior to the withdrawal of the needle, we milked the vein of its blood without stretching the tissues, and then determined the intravascular pressure. The pressure did not drop to zero, but closely approximated the tissue pressure (Table II).

TABLE II

Tissue pressure adjacent to a vein in the dorsum of the hand compared with the intravenous pressure following milking of the vein of its blood

\begin{tabular}{|c|c|c|}
\hline Subject number & Tissue pressure & $\begin{array}{l}\text { Venous pressure } \\
\text { after milking vein }\end{array}$ \\
\hline $\begin{array}{l}11 \ldots . . \\
12 \ldots . \\
13 \ldots \\
14 \ldots \\
15 . \ldots \\
\text { Mean. }\end{array}$ & \begin{tabular}{cc} 
& \multicolumn{1}{c}{$\mathrm{H}_{2} \mathrm{O}$} \\
$\ldots \ldots$ & $\mathbf{3 . 2}$ \\
$\ldots \ldots$ & 3.0 \\
$\ldots \ldots$ & $\mathbf{1 . 9}$ \\
$\ldots \ldots$ & 3.8 \\
$\ldots \ldots$ & 4.4 \\
$\ldots$ & 3.3
\end{tabular} & $\begin{array}{l}\mathrm{cm} . \mathrm{H}_{8} \mathrm{O} \\
3.6 \\
3.0 \\
2.4 \\
4.8 \\
4.6 \\
3.7\end{array}$ \\
\hline
\end{tabular}

\section{DISCUSSION}

Direct venous pressure technic. There are at present a number of technics for the determination of venous pressure directly. An addition to this number is warranted only by the demonstration of definite advantages. The following points justify our apparatus. (1) The small needle makes it possible to study directly the venous pressure in small veins. (2) Negative venous pressure may be determined. (3) It is simple and accurate. (4) The lateral openings in the needle make it possible to measure true lateral pressure. (5) There is a negligible exchange of fluid and blood between the apparatus and vein.

Frequently, it is desirable to determine the venous pressure in small veins, particularly in the hand, foot, face, or dilated veins of the chest and abdomen. The 27-gauge needle employed in our determinations lends itself readily to such vessels. Again the small size of the needle is of value not only because it is less painful but also because of the psychic effect, especially when used about the neck and face.

Although we have never made any observations of venous pressure which gave values below atmospheric pressure, the apparatus may be applied to such determinations. For example, in surgical procedures in the neck, where negative venous pressure is said to predispose to air embolism, the importance of such negative pressures may be evaluated.

The method is simple and accurate. The point of equilibrium of the meniscus is disturbed by changes of less than one millimeter of water, so that venous pressure determinations are accurate to at least one millimeter of water. Therefore, with this technic, results are as accurate as the determination of heart level. The simplicity of the method is self-evident.

The fact that the lateral openings in the needle make it possible to measure true lateral pressure is important, particularly in the determination of venous pressure when the flow is rapid. This is especially true when venous pressure is determined under experimental conditions above heart level when the Bernoulli phenomenon becomes increasingly important with rapid flow.

One might think that the lateral openings would offer certain disadvantages, viz. a weakening of the walls of the needle to the point of danger in its use, and the small size of the openings (0.35 mm. diameter) affecting the accuracy of the determinations. The needles are surprisingly strong and in over 200 determinations have never shown any signs of weakness. The second objection is eliminated by the fact that the readings are made when the meniscus in the adapter is not in motion and the venous and manometric pressures are in equilibrium. Landis (3) has pointed out that with elimination of resistance to flow, pressure measurements can be made at absolute equilibrium through an orifice as small as 8 micra.

Since there is a negligible exchange of fluid and blood between the apparatus and vein, the question of the effect of such disturbances upon the venous pressure values is eliminated.

\section{Comparison of direct and indirect venous pressure technics}

Eyster (4) states that results obtained by direct and indirect methods are practically identical. The comparisons of Brams et al. (5) showed no consistent relationship. They did not state whether the values were obtained from the same site by both methods and, indeed, we have found no such reports in the literature. 
The end points used in the indirect methods described in the literature vary $(1,5,6,7,8)$. Hooker (1) states that the point at which the shadow cast by oblique illumination of the vein comes and goes with slight oscillation of the outside pressure is the more accurate end point. Krogh, Turner, and Landis (8) used as the end point " the level where the thin blue line marking a very small amount of blood flowing in the flattened vein first reappeared after it had been driven out by a somewhat higher pressure." Brams et al. (5) in their transillumination technic collapsed the vein until the venous lumen became obliterated as a result of external pressure.

We have used the end point described as most accurate by Hooker, that is, sufficient collapse or flattening of the vessel to obliterate the shadow cast by oblique illumination. By this technic the total external pressure, acting upon the wall of the vein, is equal to the internal lateral or venous pressure. The total external pressure sufficient to obliterate completely the lumen of the vein exceeds the true lateral pressure within the vein. We deliberately chose subjects with prominent vessels in the dorsum of the hand whose vessels, with oblique illumination, cast definite shadows so as to obtain accurate end points.

In our comparison of the indirect and direct venous pressure technics, determinations were made on the same portion of the same vein without a change in position of the part. In this way errors caused by variations from heart level and by other influences, such as pressure gradient and venous compression from postural change, were eliminated. Under these conditions, we controlled as far as possible all variable factors except differences in technic. The possible temporary psychic influence of the venepuncture upon the venous pressure apparently did not influence the determinations, for repetitions of the readings with the needle in situ gave constant results.

Figure 1 illustrates the interplay of tissue pressure and intravascular venous pressure on the vessel wall. Arrows $(a)$ represent the tissue pressure, arrows $(b)$ the venous pressure, and arrows $(c)$ the effective, or resultant, pressure. It is clear that in an indirect method, when the external pressure applied plus the tissue pressure just exceeds the intravascular pressure, collapse will ensue. Such a measurement is in error, at least by the value of the tissue pressure. This, however, is not true for values obtained by a direct technic. It becomes evident that with the use of the direct method one determines the true intravascular lateral pressure (Figure $1(b)$ ), whereas with the use of an indirect method one determines essentially the difference between true intravascular lateral pressure and subcutaneous tissue pressure (Figure $1(c)$ ). Theoretically, then, the application of an indirect and a direct method to the same vessel will give lower values for the former technic. This is confirmed by our results in the ten patients studied. After taking the venous pressure with the needle in situ we milked the vein of its blood without stretching the tissues and then determined the intravascular pressure. The pressure did not drop to zero, but closely approximated the tissue pressure. This confirms the relationship illustrated in Figure 1. Furthermore, when the values obtained by the indirect technic were added to the tissue pressure values, results closely approximated the direct determinations of venous pressure (Table I).

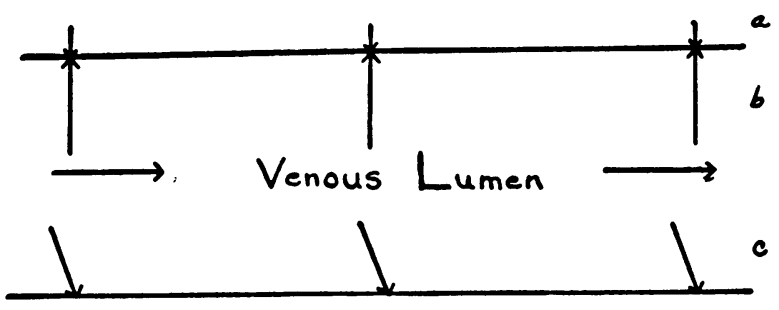

Fig. 1. Illustrating the Interplay of the Mechanical Pressures on the Venous Wali; Tissue Pressure (a), Intravascular Pressure (b), and Resultant, or Effective Pressure (c) Withstanding Collapse Pressure

\section{CONCLUSIONS}

1. The application of the tissue pressure apparatus to the direct determination of venous pressure was highly satisfactory and disclosed definite advantages.

2. Comparison of indirect and direct determinations of venous pressure on the same vessel indicates that the former are in error by approximately the tissue pressure. This factor becomes 
increasingly important as the venous pressure decreases.

\section{BIBLIOGRAPHY}

1. Hooker, D. R., The influence of age upon the venous blood pressure in man. Am. J. Physiol., 1916, 40, 43.

2. Burch, G. E. and Sodeman, W. A., The estimation of the subcutaneous tissue pressure by a direct method. J. Clin. Invest., 1937, 16, 845.

3. Landis, E. M., Micro-injection studies of capillary blood pressure in human skin. Heart, 1929-31, 15, 209.
4. Eyster, J. A. E., The Clinical Aspects of Venous Pressure. Macmillan Company, New York, 1929, p. 30.

5. Brams, W. A., Katz, L. N. and Schutz, W. J., Intravenous pressure. I. New method of determination. Arch. Int. Med., 1933, 51, 33.

6. McIntire, J. M. and Turner, A. H., Venous pressure and posture in normal young women. J. Clin. Invest., 1935, 14, 16.

7. Hooker, D. R., Observations on the venous blood pressure in man. Am. J. Physiol., 1914, 35, 73.

8. Krogh, A., Turner, A. H. and Landis, E. M., A celluloid capsule for measuring venous pressure. J. Clin. Invest., 1932, 11, 357. 